\title{
Biosorption potentials of sawdust in removing zinc ions from aqueous solution
}

\author{
Kayode Michael Ogunjobi ${ }^{*}$, Victor Adeoluwa Jayeola1, Oluwaseun Friday Gakenou², Opeyemi \\ Oluwaseun Olufemi ${ }^{1}$, Samuel Oluwafemi Ayanleye ${ }^{3}$, Kudirat Jumoke Lawal ${ }^{4}$
}

\author{
${ }^{1}$ Department of Forestry and Wildlife Management, Federal University of Agriculture Abeokuta, Nigeria \\ ${ }^{2}$ Department of Forest and Wood Science, Stellenbosch University, South Africa \\ ${ }^{3}$ Department of Forestry and Wood Technology, Federal University of Technology Akure, Nigeria \\ ${ }^{4}$ Department of Sustainable Bioproducts, Mississippi State University, USA
}

\begin{abstract}
:
Timber processing industries generate enormous waste, which constitutes environmental nuisance. However, the sawdust contains several organic compounds that could actively remove heavy metal ions from an aqueous solution through the adsorption process. This study investigated the efficacy of sawdust of Albizia zygia and Gmelina arborea in removing Zinc (II) under two factors affecting adsorption, Contact time and $\mathrm{pH}$. Sawdust samples were sieved through a screen size of $2.0 \mathrm{~mm}$, after which a portion of sawdust for each species was subject to pre-treatment by boiling while the other parts were kept as control samples (untreated). The effect of $\mathrm{pH}$ on the removal efficiency of the biosorbent was determined by adding $0.2 \mathrm{~g}$ of the sawdust (treated and untreated) into six conical flasks containing the metal solution (50ppm) at different $\mathrm{pH}$ values. There was a significant difference in the removal efficiency of both treated and untreated samples for both species. Removal efficiency also increased with time, with maximum $\mathrm{Zn}$ (II) biosorption achieved at 90 minutes. Removal efficiency increased with $\mathrm{pH}$ and reached optimum $\mathrm{pH}$ of 4 . Both species' maximum $\mathrm{Zn}$ (II) biosorption (Albizia zygia $=17.22$, Gmelina arborea $=17.92$ ) compared favourably with other biosorbent used in previous studies. From this study and based on availability, cost-effectiveness, ability to be recovered and reused, sawdust of Albizia zygia and Gmelina arborea are proven alternative adsorbents treatment of water towards ensuring that quality water is available for humans, plants, and animals.
\end{abstract}

Keywords: Adsorption, Adsorbent, contaminated water, Sawdust, Zinc ion.

\section{Introduction}

Water pollution has become a severe challenge in our present world. The primary sources of freshwater pollution can be attributed to the discharge of untreated sanitary, toxic industrial wastes, dumping of industrial effluents, and runoff from agricultural fields ${ }^{1,2}$. These industrial and municipal wastewaters frequently contain heavy metal ions ${ }^{3}$ such as lead, copper, cadmium, zinc, and nickel, which have been the most common pollutants found in industrial effluents ${ }^{4}$. Consumption of these heavy metals in drinking water has been hazardous to human health as it damages the liver and nerves and blocks functional groups of vital enzymes and bones ${ }^{5}$.

Heavy metals have been identified as the most problematic micropollutants in water ${ }^{6}$ because of their nondegradability and severe toxicity ${ }^{7}$. They also have the potential for long-term contamination even at a concentration below allowable limits due to their accumulative nature ${ }^{8}$. They can move throughout the food chain ${ }^{9}$. One of the heavy metals considered in this study is zinc, which commonly exists as $\mathrm{Zn}^{2+}$ in an aqueous solution. According to $\mathrm{WHO}^{10}$, the permissible limit for $\mathrm{Zn}^{2+}$ in drinking water is $3.0 \mathrm{mg} / \mathrm{L}$. However, high concentration can cause metal fume fever, restlessness, skin irritations, anaemia, and nausea ${ }^{2}$. A global sanitation report by $\mathrm{WHO} / \mathrm{UNICEF}^{11}$ revealed that " 70 to $80 \%$ of all illnesses in developing countries are related to water contamination, particularly susceptible to children and women"2. 
The efficient removal of heavy metals from water and minimizing risk presents a new challenge for water managers and industries ${ }^{12}$. The conventional methods used to remove these heavy metals from water and wastewater include chemical precipitation, chemical oxidation/reduction, electrochemical treatment, filtration, evaporation recovery, reverse osmosis, ion-exchange, and electro-coagulation ${ }^{13}$, which have become unsustainable. However, these methods also have significant disadvantages, which include incomplete removal, expensive, high-energy requirements, aggregation of metal residues, and production of toxic sludges $^{14,15}$. Conversely, adsorption technology has emerged as an improved treatment technique ${ }^{15,16}$, with a growing interest in developing practical and low-cost adsorbents for industrial application ${ }^{2,5}$.

For decades, activated carbon has been a good candidate for adsorbing pollutants due to its porous structure with a surface area ranging from 600 to $2000 \mathrm{~m}^{2} / \mathrm{g}^{1}$, compared to other biosorbent materials ${ }^{17}$. However, its applications are limited because its production process is expensive, and it cannot regenerate quickly. It is, therefore, essential to note that cost is a crucial factor in selecting a suitable commercial adsorbent. An adsorbent is considered low-cost or cheap "if it is abundant in nature, requires little processing, and is a byproduct of waste material from waste industry"2.

Biosorption, which uses natural materials such as wastes from agricultural and industrial activities and microorganisms as an adsorbent in removing metal ions from an aqueous solution ${ }^{2}$, has proven very useful and cost-effective commercial adsorbent for industrial application over the past two decades. This method has significant advantages: low operational cost, high efficiency, regeneration of biosorbent, and removal of contaminants even in low concentration, which is another major limitation for most conventional approaches $^{15}$.

Forest industries in Nigeria generate enormous waste materials. In 2010, sawmills in Nigeria generate over $1,000,000 \mathrm{~m}^{3}$ of wood wastes while plywood mills generated about $5,000 \mathrm{~m}^{3}$ of waste, most of which are disposed of poorly and consequently contribute to environmental degradation ${ }^{18}$. The sawdust from wood contains cellulose, hemicelluloses, lignin, ash, tannins, and other phenolic compounds (active ion-exchange compounds that could bind heavy metal ions) ${ }^{19}$; they are cheap and abundantly available. Investigating the potentials of sawdust generated from some of the most processed wood species in Nigeria as adsorbents in removing heavy metals from the contaminated water have become imperative. The use of sawdust as a viable biosorbent presents a novel approach in managing this abundant industrial by-product in an economical and environmental-friendly manner. Therefore, this study investigated the adsorbent potential of sawdust from two important wood species, Albizia zygia and Gmelina arborea, in removing $\mathrm{Zn}^{2+}$ from contaminated water.

\section{Materials and method}

\section{The adsorbent used and preparation.}

The sawdust collected was first screened through a sieve of screen size $2.0 \mathrm{~mm}$, to obtain uniformly sized particles used for the adsorption tests in this study. The sieved sawdust was divided into two halves, with each weighing 75 grams. One-half of each species' divided portion was boiled for 1 hour, washed with clean water, and cooked for another 1 hour to effectively remove a large percentange of extractives present. The remaining was left untreated. The samples from the wood species (treated and untreated) were dried at $105^{\circ} \mathrm{C}$ for 2 hours using an oven to remove moisture from the sawdust before adsorption studies.

\section{Inducement of zinc $\left(\mathrm{Zn}^{2+}\right)$ into an aqueous solution}

$2.085 \mathrm{~g}$ of Zinc chloride $\left(\mathrm{ZnCl}_{2}\right)$ salt was dissolved in $1 \mathrm{~L}$ of deionized water to obtain a 1000ppm stock solution of $\mathrm{Zn}^{2+}$. Standard dilution formula (equation 1) was applied to prepare 50ppm used as the working solution by pipetting $50 \mathrm{ml}$ of the $1000 \mathrm{ppm}$ metal stock solution into a beaker $(1 \mathrm{~L})$ and was made up to the final volume using distilled water. $50 \mathrm{ml}$ from the new working solution was transferred into a 100ml Pyrex glass conical flask, and this was used for the batch biosorption studies. All chemicals used were of analytical grade.

$$
\mathrm{C}_{1} \mathrm{~V}_{1}=\mathrm{C}_{2} \mathrm{~V}_{2}
$$

Where $\mathrm{C}_{1}$ is the stock concentration $(1000 \mathrm{ppm}), \mathrm{V}_{1}$ is the new stock volume required, $\mathrm{C}_{2}$ is the concentration of the working solution needed (50ppm), $\mathrm{V}_{2}$ is the final volume of dilution $(1000 \mathrm{ml})$ 


\section{Batch biosorption studies}

In this study, batch experiments were performed by adding $0.2 \mathrm{~g}$ of the biosorbent (treated and untreated sawdust) into the pyres glass conical flask containing $50 \mathrm{ml}$ of the metal solution and placed on an orbital shaker operating at $120 \mathrm{rpm}$ (rotation per minute) at room temperature. The effect of $\mathrm{pH}$ on the adsorption capacity of the biosorbent was determined by adding $0.2 \mathrm{~g}$ of the sawdust (treated and untreated) into six conical flasks containing the metal solution $(50 \mathrm{ppm})$ at different $\mathrm{pH}$ values. The working solutions' $\mathrm{pH}$ was adjusted (to values of $2,3,4$ ) using $0.1 \mathrm{M} \mathrm{NaOH}$ and $0.1 \mathrm{M}$ HCL, monitored with a pocket-sized Hanna $\mathrm{pH}$ meter. The six biosorption mixtures were agitated for 300mins and analyzed at different $\mathrm{pH}$. For contact time, the metal solution's $\mathrm{pH}$ in the six conical flasks was adjusted to 4 , and $0.2 \mathrm{~g}$ of the sawdust was added to each solution. The samples were agitated and analyzed at different contact times (60, 90 and 120 minutes). For both studies, samples were filtered using Whatman filter paper, and the supernatant was analyzed for $\mathrm{Zn}^{2+}$ by an atomic absorption spectrometer (Thermo Scientific S4 AA System). The biosorption capacity (mg/g) and removal efficiency $(\% \mathrm{R})$ was calculated using the following equation.

$$
\begin{aligned}
& \qquad \mathrm{qe}=\frac{(C i-C e) V}{m} \\
& \text { Removal efficiency }=\frac{C i-C e}{C i} \times 100
\end{aligned}
$$

Where qe is the amount of metal ion adsorbed on the biosorbent $(\mathrm{mg} / \mathrm{g}), \mathrm{C}_{i}$ and $\mathrm{C}_{e}$ are the initial and final ion concentrations $(\mathrm{mg} / \mathrm{L})$ respectively, $\mathrm{V}$ is the volume of the medium used $(\mathrm{L})$, and $\mathrm{m}$ is the amount of biomass used (g).

\section{Data analysis}

This study's experimental design was a $2 \times 2 \times 3$ factorial experiment; two sawdust species, two treatments (treated and untreated for the wood species), and three levels of $\mathrm{pH}$ and time as factors. Descriptive statistics to present the mean and standard deviation for each wood species were performed using the "rstatix package" ${ }^{20}$. Analysis of variance was tested using the "RcmdrMisc package" 21 in the R system for statistical computing (R Core Team, 2020).

\section{Results and discussion Effect of contact time}

Figure 1 presents the mean values for the removal efficiency of treated and untreated sawdust of Gmelina arborea and Albizia zygia at different contact times. The sawdust of Albizia zygia had a slightly higher removal efficiency (64.82\%) than the sawdust of Gmelina arborea (64.24\%). Time had no significant influence on the adsorption capacity of the species. The treated sawdust of Albizia zygia had an average removal efficiency of $62.50 \%$, with its highest $(63.33 \%) \%$ removal recorded at 90 minutes contact time. However, the untreated Albizia zygia sawdust had an average removal efficiency of $67.14 \%$, with the highest $(67.29 \%) \%$ removal observed at 120 minutes contact time. For Gmelina arborea, the result revealed that the treated sawdust samples had an average removal efficiency of $61.18 \%$, with its highest $(61.46 \%)$ removal efficiency observed at 120 minutes contact time. On the other hand, the untreated sawdust samples had an average removal efficiency of $67.29 \mathrm{mg} / \mathrm{g}$, with its highest $(68.25 \mathrm{mg} / \mathrm{g})$ recorded at 90 minutes. Contact time is an "important parameter that determines the best operational conditions in a continuous process of ions removal" 22 . The time to reach maximum biosorption depends on the type of biosorbent, metal ion, and interaction ${ }^{15}$. Biosorption consists of two phases: an initial rapid stage, where approximately $90 \%$ of the metal-binding occurs due to free active sites available for metal ion biosorption ${ }^{15}$, and in the slow phase, biosorption decreases due to saturation of the metal-binding sites ${ }^{23}$. In this study, it was observed that the highest removal efficiency $(68.25$ $\mathrm{mg} / \mathrm{g}$ ) was recorded at 90 minutes, which can be presumed to be the equilibrium time where equilibrium metal ion concentration was achieved. This equilibrium time agrees with Shobana ${ }^{24}$, who recorded the highest adsorption $(70.10 \mathrm{mg} / \mathrm{g})$ at 90 minutes. However, the equilibrium time observed in this study is higher than 30 minutes reported by ${ }^{23}$, who used microorganisms (Pseudomonas aeruginosa and Bacillus cereus) to remove $\mathrm{Zn}$ (II) from aqueous solutions.

The result of ANOVA presented in Table 1 showed that only the effect of treatment was significantly different $(\mathrm{P}<0.05)$. The treatment's main effect yielded $\mathrm{F}(1,24)=14.735, \mathrm{p}<0.05$, indicating that the average removal efficiency of untreated sawdust samples was significantly higher than that of the treated samples. 


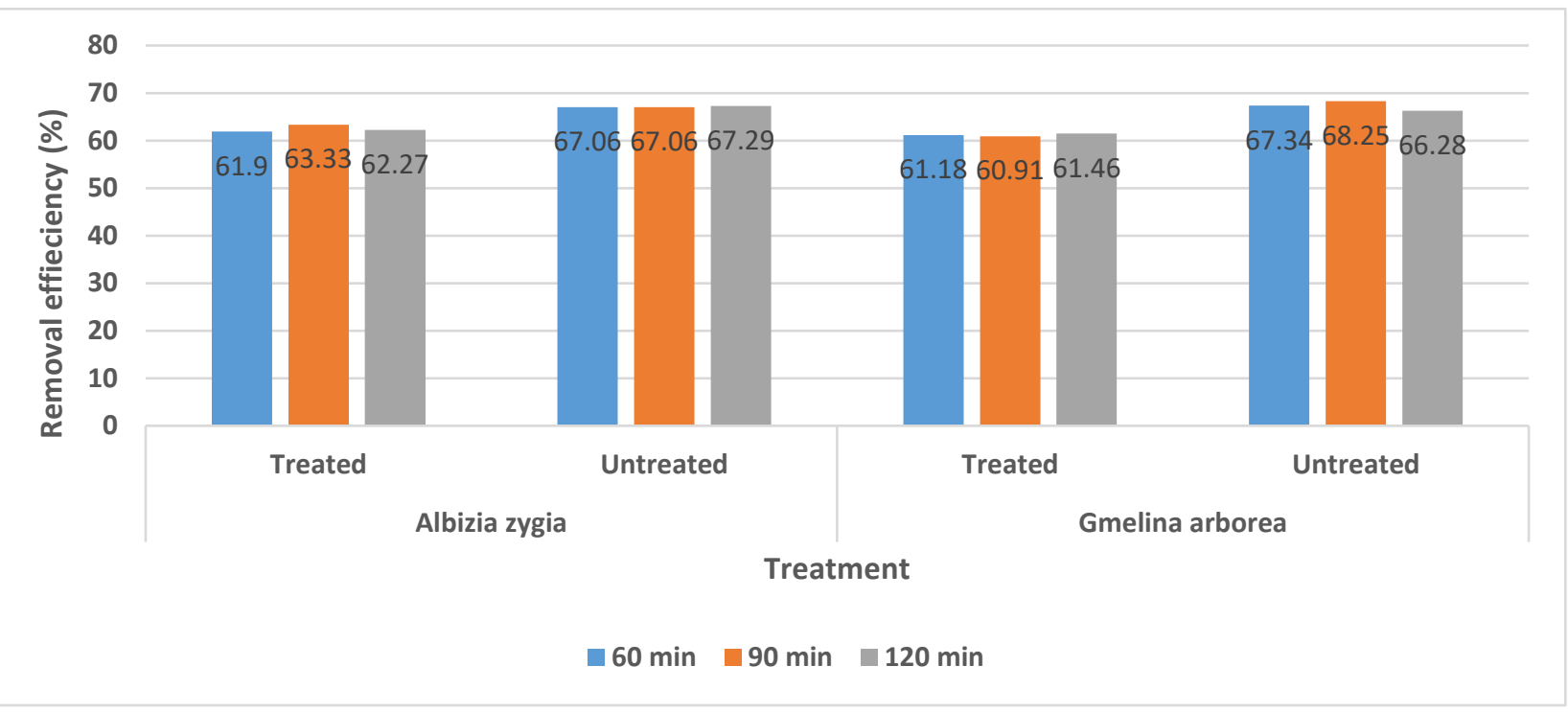

Figure 1. Removal efficiency of treated and untreated sawdust at different contact time.

Table 1. Analysis of variance showing the effect of species, treatment and contact time.

\begin{tabular}{ccc}
\hline Source of Variation & Df & Absorption rate \\
\hline Species & 1 & $0.173 \mathrm{~ns}$ \\
Treatment & 1 & $14.735^{* *}$ \\
Contact time & 2 & $0.066 \mathrm{~ns}$ \\
Species * Treatment & 1 & $0.274 \mathrm{~ns}$ \\
Species * Contact time & 2 & $0.021 \mathrm{~ns}$ \\
Treatment * Contact time & 2 & $0.027 \mathrm{~ns}$ \\
Species * Treatment* Contact time & 2 & $0.161 \mathrm{~ns}$ \\
Error & 24 & \\
Total & 36 & \\
\hline
\end{tabular}

** Significant at $\mathrm{p}<0.05$

ns - not significant

\section{Effect of pH}

Results from the study showed that $\mathrm{pH}$ had significant effects on the adsorbent potential of the sawdust. The mean values for the removal efficiency of treated and untreated sawdust of Gmelina arborea and Albizia zygia at different $\mathrm{pH}$ levels are presented in Figure 2. For Albizia zygia, it was observed that the treated sawdust had an average removal efficiency of $67.10 \%$, with its highest $(67.42 \%)$ removal efficiency recorded at $\mathrm{pH}$ 4. On the other hand, the untreated Albizia zygia sawdust had an average removal efficiency of $70.64 \%$, in which the highest $(71.60 \%)$ removal efficiency was observed at $\mathrm{pH} 4$. For Gmelina arborea, the result showed that the treated sawdust samples had an average removal efficiency of $67.66 \%$, with its highest $(68.36 \%)$ removal efficiency observed at $\mathrm{pH} 4$. On the other hand, the untreated sawdust samples had an average removal efficiency of $75.71 \%$, with its highest $(76.26 \%)$ removal efficiency recorded at $\mathrm{pH} 4$.

$\mathrm{pH}$ indicates the degree of acidity or alkalinity of a solution on a logarithmic scale where seven is neutral, lower values are acidic, and higher values are alkaline. $\mathrm{pH}$ is one of the essential physicochemical factors influencing the biosorption process because of its role in metal chemical speciation and solubility and the total charge of the biosorbent ${ }^{15,25}$. At low $\mathrm{pH}$ (acidic condition), the hydronium ions $\left(\mathrm{H}_{3} \mathrm{O}^{+}\right)$are attracted to the biosorbent. Therefore, there will be a competition between the protons in the solution and the positively charged metal ions at the binding sites, which will reduce the biosorption process ${ }^{15,26}$. However, there will be an increased amount of hydroxyl ions (OH-) attracting positive-charged metal at higher $\mathrm{pH}$, thus increasing biosorption $^{25}$. Studies have reported that at higher $\mathrm{pH}$ in the Alkaline range, metal ions precipitate, and as a 


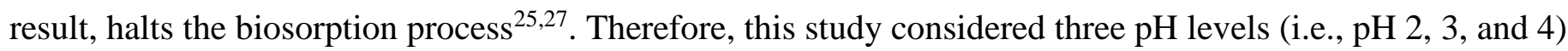
with $\mathrm{pH} 4$ as optimum ${ }^{27}$. This study agrees with the above explanation that because the rate of adsorption increased as $\mathrm{pH}$ increased, with $\mathrm{pH} 4$ having the highest adsorption rate for both treated and untreated sawdust. This study also aligns with previous findings ${ }^{24,28,29}$.

The result of ANOVA as presented in Table 2 showed that there was a statistically significant interaction between species and treatment during adsorption $\mathrm{F}(1,24)=50.676, \mathrm{p}<0.05$, indicating that the average removal efficiency of treated and untreated sawdust samples was significantly different in both wood species.

Table 2. Analysis of variance showing the effect of species, treatment, and $\mathrm{pH}$ levels.

\begin{tabular}{ccc}
\hline Source of Variation & Df & Absorption rate \\
\hline Species & 1 & $78.792^{* *}$ \\
Treatment & 1 & $335.414^{* *}$ \\
pH level & 2 & $4.087^{*}$ \\
Species * Treatment & 1 & $50.676^{* *}$ \\
Species * pH level & 2 & $2.110 \mathrm{~ns}$ \\
Treatment * pH level & 2 & $0.165 \mathrm{~ns}$ \\
Species * Treatment * pH level & 2 & $0.585 \mathrm{~ns}$ \\
Error & 24 & \\
Total & 36 & \\
\hline
\end{tabular}

*significant at $\mathrm{p}<0.01, * *$ significant at $\mathrm{p}<0.05, \mathrm{~ns}-$ not significant

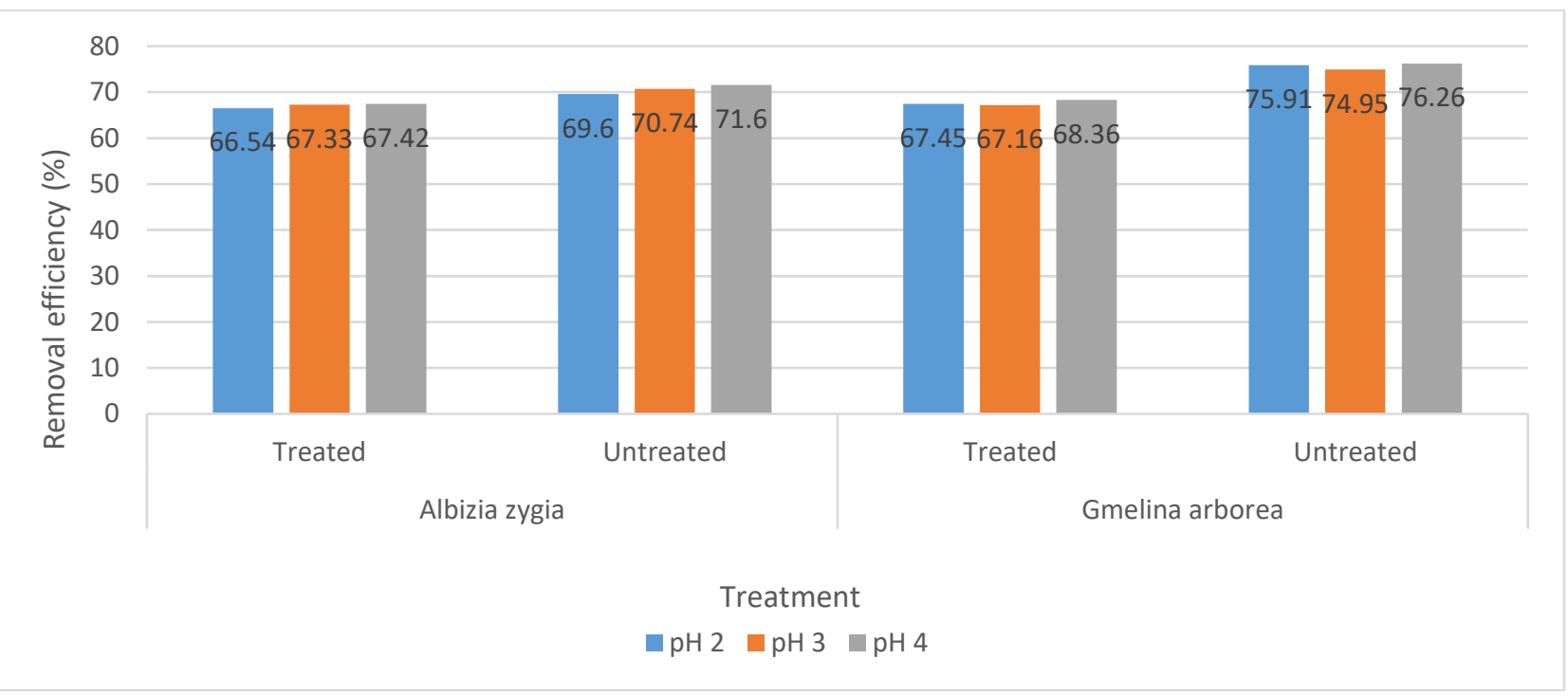

Figure 2. The removal efficiency of treated and untreated sawdust at different $\mathrm{pH}$ levels.

The sawdust of both wood species used in this study showed great potential as a low-cost adsorbent for industrial application. It compares favourably with different materials used in removing Zn (II), as presented in Table 3.

Table 3. Biosorption of zinc ions using various biosorbents from the literature.

\begin{tabular}{|c|c|c|c|c|c|}
\hline Adsorbent & Type & $\begin{array}{c}\text { Adsorption } \\
\text { capacity }(\mathrm{mg} / \mathrm{g})\end{array}$ & pH & $\begin{array}{c}\text { Initial } \\
\text { concentration } \\
\text { range }\left(\mathrm{mg} \mathrm{l}^{-1}\right)\end{array}$ & Reference \\
\hline
\end{tabular}

$\begin{array}{ccccc}\begin{array}{c}\text { Bagasse } \\ \text { carbon }\end{array} & \begin{array}{c}\text { Activated } \\ \text { carbon }\end{array} & 31.11 & 4.5 & 1-1000\end{array}$




\begin{tabular}{cccccc}
$\begin{array}{c}\text { Fontinalis } \\
\text { antipyretica }\end{array}$ & $\begin{array}{c}\text { Aquatic } \\
\text { moss }\end{array}$ & 15.0 & 5.0 & 100 & 30 \\
$\begin{array}{c}\text { Botrytis } \\
\text { cinerea }\end{array}$ & Biomass & 12.98 & $5.0-6.0$ & 100 & 31 \\
$\begin{array}{c}\text { Sea nodule } \\
\text { residue }\end{array}$ & $\begin{array}{c}\text { Solid } \\
\text { waste }\end{array}$ & 21.09 & na. & na. & 32 \\
$\begin{array}{c}\text { Acinetobacter } \\
\text { sp }\end{array}$ & Bacteria & 36.0 & na. & na. & 33 \\
$\begin{array}{c}\text { Pinus } \\
\text { sylvestris bark }\end{array}$ & $\begin{array}{l}\text { Wood } \\
\text { waste }\end{array}$ & 40.0 & 6.1 & 1045 & 34 \\
$\begin{array}{c}\text { Albizia zygia } \\
\text { sawdust }\end{array}$ & $\begin{array}{c}\text { Wood } \\
\text { waste }\end{array}$ & 17.22 & $2.0-4.0$ & 50 & Current study \\
$\begin{array}{c}\text { Gmelina } \\
\text { arborea } \\
\text { sawdust }\end{array}$ & Wood & 17.92 & $2.0-4.0$ & 50 & Current study \\
\hline
\end{tabular}

na. $=$ not available

\section{Conclusions}

Sawdust is a cheap and effective adsorbent for the removal of $\mathrm{Zn}$ (II) from contaminated water. Therefore, sawdust that is customarily burnt and contributes to air pollution can be harnessed to improve water quality at a comparatively lower cost. This study showed that the untreated sawdust had higher adsorption properties. Future studies will be interesting to compare with other pre-treatment methods and consider other factors affecting adsorption, such as the effect of temperature, initial metal concentration, biosorbent dose, agitation speed. Another critical direction can be applying this biosorbent in real wastewaters/effluents as literature reveal that real wastewaters/effluents affect biosorption due to other metals' presence. However, based on availability, cost-effectiveness, ability to be recovered and reused, sawdust of Albizia zygia and Gmelina arborea can be recommended as effective adsorbents in the treatment of water towards ensuring that quality water is available for humans, plants, and animals.

\section{References}

1. Bhatnagar M, Sillanpää M (2010) Utilization of agro-industrial and municipal waste materials as potential adsorbents for water treatment--A review. Chemical Engineering Journal, 157 (2-3): p. 277-296.

2. Zwain HM, Vakili M, Dahlan I (2004) Waste Material Adsorbents for Zinc Removal from Wastewater: A Comprehensive Review. International Journal of Chemical Engineering, vol. 2014, 13 pages.

3. Demirbas A (2008) Heavy metal adsorption onto agro-based waste materials: A review. Journal of Hazardous Materials, 157 (2-3): 220-229.

4. Djeribi R, Hamdaoui O (2008) Sorption of Copper (II) from aqueous solutions by cedar sawdust and crushed brick. Desalination 225 (1-3): 95-112.

5. Awwad NS, El-Zahhar AA, Fouda AM, Ibrahium HA (2013) Removal of heavy metal ions from ground and surface water samples using carbons derived from date pits. Journal of Environmental Chemical Engineering, 1(3): 416-423.

6. Simionato JI, Guerra LD, Keller M, Garcia FA, Garci JC (2014) Application of chitin and chitosan extracted from silkworm chrysalides in the treatment of textile effluents contaminated with remazol dyes. Acta Scientiarum Technology Maringá. 36 (4): 693-698. 
7. Bozic D, Stankovic V (2009) Adsorption of heavy metal ions by sawdust of deciduous trees. Journal of Hazardous Materials, 171 (1-3): 684-692.

8. Ahmad A, Rafatullahb MO, Sulaimanb M, HakimiIbrahima Y, Chiia Y, Bazlul MS (2009) Removal of $\mathrm{Cu}(\mathrm{II})$ and $\mathrm{Pb}$ (II) ions from aqueous solutions by adsorption on sawdust of Meranti wood. Desalination 247: 636-646.

9. Igwe JC, Abia AA (2006) A bioseparation process for removing heavy metals from wastewater using biosorbents. African Journal of Biotechnology, vol. 5 (11), 1167-1179.

10. WHO (2011) Revised Drinking Water Guidelines to Prevent Waterborne Disease. World Health Organization. https://who.int/water_sanitation_health/events/press_backgrounder/en/

11. WHO / UNICEF Joint Monitoring Programme for Water Supply and Sanitation (2000) Global Water Supply and Sanitation Assessment 2000 Report. World Health Organization. https://apps.who.int/iris/handle/10665/42352

12. Luo Y, Guo W, Ngo HH, Nghiem LD, Hai FI, Zhang J, Liang S, Wang XC (2014) A review on the occurrence of micropollutants in the aquatic environment and their fate and removal during wastewater treatment. Science of the Total Environment March 1; 473-474: 619-41.

13. Babel S, Kurniawan TA (2003) Low-cost adsorbents for heavy metals uptake from contaminated water- a review. Journal of Hazardous Materials 97 (1-3): 219-43.

14. Jang A, Seo Y, Bishop PL (2005). The removal of heavy metals in urban runoff by sorption on mulch. Environmental Pollution 133: 117-127.

15. Kanamarlapudi SLRK, Chintalpudi VK, Muddada S (2018) Application of Biosorption for Removal of Heavy Metals from Wastewater. In J. Derco \& B. Vrana (Eds.), Biosorption. IntechOpen. https://doi.org/10.5772/intechopen.77315

16. Devanna N, Begum BA, Chari MA (2019) Low-Cost Adsorbents procedure by means of Heavy Metal Elimination from Wastewater. Preprints, February. https://doi.org/10.20944/preprints201902.0013.v1

17. Kurniawan TA, Chan GYS (2006) Comparisons of low-cost adsorbents for treating wastewaters laden with heavy metals. Science of The Total Environment 366 (2-3): 409-426.

18. Ogunwusi AA (2014) Wood waste generation in the forest industry in Nigeria and prospects for its industrial utilization. Civil and Environmental Research 6: 62-70.

19. Shukla A, Zhang YH, Dubey P, Margrave JL, Shukla SS (2002) The role of sawdust in the removal of unwanted materials from water. Journal of Hazardous Materials, 95 (1-2): 137-152.

20. Alboukadel A (2020). rstatix: Pipe-Friendly Framework for Basic Statistical Tests. R Package version 0.6.0. https://CRAN.R-project.org/package=rstatix.

21. John F (2020) RcmdrMisc: R Commander Miscellaneous Functions. R package version 2.7.1. https://CRAN.R- project.org/package=RcmdrMisc.

22. Abdel-Ghani NT, Hegazy AK, El-Chaghaby GA (2009) Typha domingensis leaf powder for decontamination of aluminium, iron, zinc and lead: Biosorption kinetics and equilibrium modeling. International Journal of Environmental Science and Technology, Vol. 6, Issue 2, pp. 243-248.

23. Joo JH, Hassan SHA, Oh SE (2010) Comparative study of biosorption of Zn2+ by Pseudomonas aeruginosa and Bacillus cereus. International Biodeterioration and Biodegradation, 64 (8), 734 741.

24. Shobana V, Anusha PG, Thejeshwar RD, Nayana S (2017) Removal of Zinc ( $\mathrm{Zn}^{2+}$ ) from wastewater by Mangifera indica peel. International Journal of Advances in Scientific Research and Engineering 3 (24): 238-246.

25. Hlihor RM, Bulgariu L, Sobariu DL, Diaconu M, Tavares T, Gavrilescu M (2014) Recent advances in biosorption of heavy metals: Support tools for biosorption equilibrium, kinetics and mechanism. Revue Roumaine de Chimie, 59 (6-7), 527-538.

26. Jihyun L, Hee-Man K, Lee-Hyung K, Seok-Oh K (2008) Removal of heavy metals by sawdust adsorption: Equilibrium and kinetic studies. Environmental Engineering Research 2: 79-84.

27. Mohan D, Singh KP (2002) Single and multi-component adsorption of cadmium and zinc using activated carbon derived from bagasse - An agricultural waste. Water Research, 36 (9), 2304-2318. https://doi.org/10.1016/S0043-1354 (01)00447-X

28. Cordero B, Lodeiro P, Herrero R, deVicente ME (2004) Biosorption of cadmium by Fucus spiralis. Environmental Chemistry 1: 180-187. 
29. Abdal - Kareem, Dawagreh MA (2017) Removal of Zinc from wastewater by using Jordanian Natural Zeolite. Asian Journal of Microbiology, Biotechnology and Environmental science 19. 3: 625-630.

30. Martins RJE, Pardo R, Boaventura RAR (2004) Cadmium(II) and zinc(II) adsorption by the aquatic moss Fontinalis antipyretica: Effect of temperature, $\mathrm{pH}$ and water hardness. Water Research, 38 (3), 693-699. https://doi.org/10.1016/j.watres.2003.10.013

31. Tunali S, Akar T (2006) $\mathrm{Zn}$ (II) biosorption properties of Botrytis cinerea biomass. Journal of Hazardous Materials, 131(1-3), 137-145. https://doi.org/10.1016/j.jhazmat.2005.09.024

32. Agrawal A, Sahu KK, Pandey BD (2004) Removal of Zinc from aqueous solutions using sea nodule residue. Colloids and Surfaces A: Physicochemical and Engineering Aspects, 237(1-3), 133-140. https://doi.org/10.1016/j.colsurfa.2004.01.034

33. Tabaraki R, Ahmady-Asbchin S, Abdi O (2013) Biosorption of $\mathrm{Zn}$ (II) from aqueous solutions by Acinetobacter sp. isolated from petroleum spilled soil. (2013). Journal of Environmental Chemical Engineering, 1(3), 604-608. https://doi.org/10.1016/j.jece.2013.06.024

34. Gaballah I, Kiberus G (1994). Elimination of As, $\mathrm{Hg}$ and $\mathrm{Zn}$ from synthetic solutions and industrial effluents using modified bark, in: M. Misra (Ed.), Separation Process: Heavy Metals, Ions and Materials, The Mineral, Metals and Materials Society. Pp. 15 - 26. 